University of South Florida

DIGITAL COMMONS

Digital Commons @ University of

@ UNIVERSITY OF SOUTH FLORIDA

South Florida

$1-1-2011$

\title{
2011 Annual Report USF Polytechnic
}

USF

Follow this and additional works at: https://digitalcommons.usf.edu/usf_accountability_reports

\section{Scholar Commons Citation}

USF, "2011 Annual Report USF Polytechnic" (2011). USF Accountability Reports. 16.

https://digitalcommons.usf.edu/usf_accountability_reports/16

This Article is brought to you for free and open access by the USF Archives at Digital Commons @ University of South Florida. It has been accepted for inclusion in USF Accountability Reports by an authorized administrator of Digital Commons @ University of South Florida. For more information, please contact digitalcommons@usf.edu. 


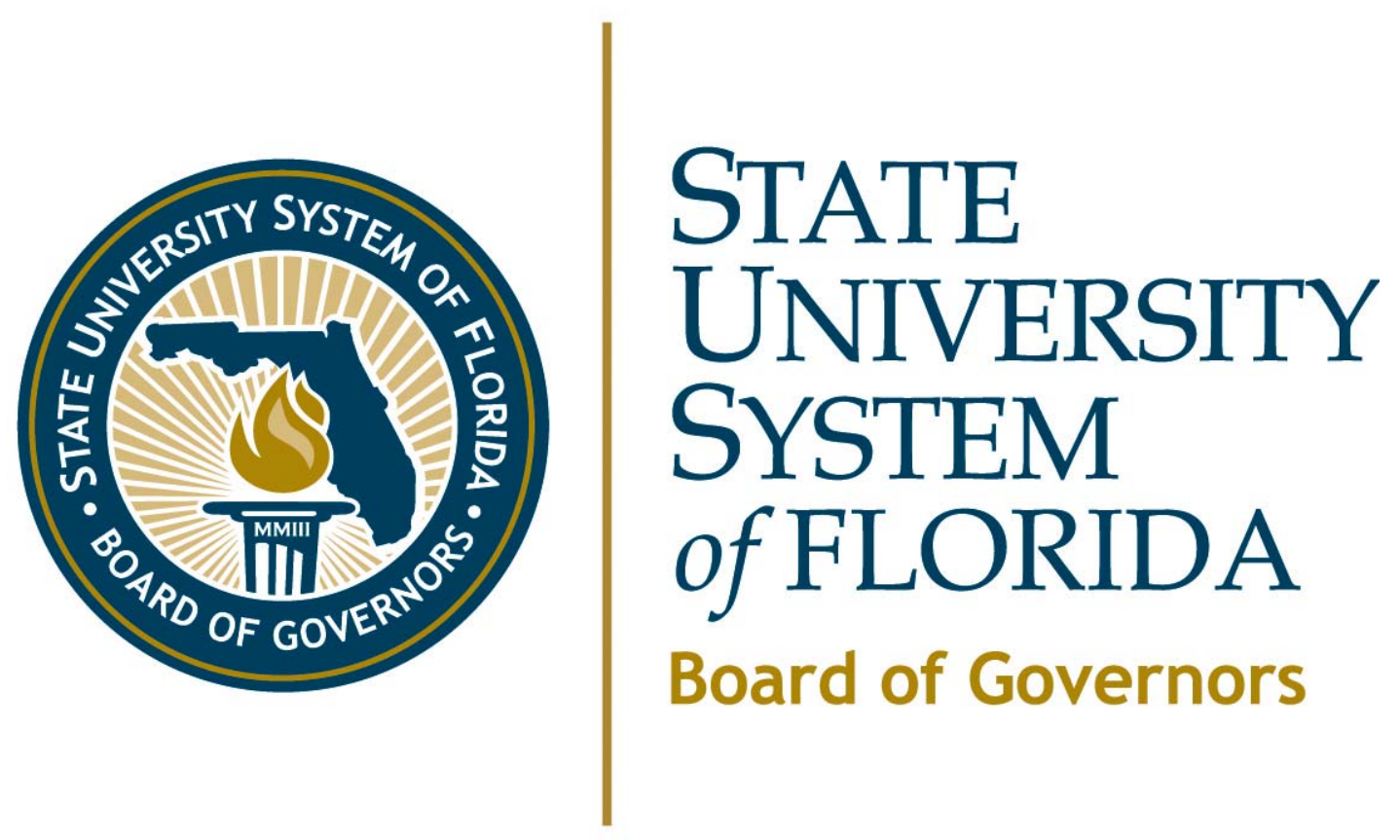

University of South Florida - Polytechnic 2010-11 Annual Report 
Data definitions are provided in the Appendices.

\footnotetext{
Note concerning data accuracy: The Office of the Board of Governors believes that the accuracy of the data it collects and reports is paramount to ensuring accountability in the State University System. Thus, the Board Office allows university resubmissions of some data to correct errors when they are discovered. This policy can lead to changes in historical data.
} 


\section{TABLE OF CONTENTS}

Dashboard page 1

Key Achievements

Narrative Report.............................. page 4

Data Tables.................................. page 11

\section{Section 1 - Financial Resources}

[Not every university will have HSC \& IFAS tables.]

TABLE 1A. University Education and General Revenues

1B. University Education and General Expenditures

1C. State Funding per Full-Time Equivalent (FTE) Student

1D. University Other Budget Entities

1E. University Total Revenues and Expenditures

1F. Voluntary Support of Higher Education

1G. University Federal Stimulus Dollars (ARRA)

1H. HSC - Education and General Revenues

1I. HSC - Education and General Expenditures

1J. HSC - Faculty Practice Plans

1K. IFAS - Education and General Revenues

1L. IFAS - Education and General Expenditures

\section{Section 2 - Personnel}

TABLE 2A. Personnel Headcount

\section{Section 3 - Enrollment}

TABLE 3A. University Full-Time Enrollment (FTE)

3B. Enrollment by Location

\section{Section 4 - Undergraduate Education}

TABLE 4A. Baccalaureate Degree Program Changes in AY 2009-2010

4B. First-Year Persistence Rates

4C. Federal Definition - Undergraduate Progression and Graduation Rates for Full-Time,

First-Time-in-College (FTIC) Students
Section 4 - Undergraduate Education (continued)

TABLE 4D. SUS Definition - Undergraduate Progression and Graduation Rates for Full- \& Part-Time, First-Time-in-College (FTIC) Students

4E. SUS Definition - Undergraduate Progression and Graduation Rates for AA Transfer Students

4F. SUS Definition - Undergraduate Progression and Graduation Rates for Other Transfer Students

4G. Baccalaureate Degrees Awarded

4H. Baccalaureate Degrees Awarded in Areas of Strategic Emphasis

4I. Baccalaureate Degrees Awarded to Underrepresented Groups

4J. Baccalaureate Completion Without Excess Credit Hours

4K. Undergraduate Course Offerings

4L. Faculty Teaching Undergraduates

4M. Undergraduate Instructional Faculty Compensation

4N. Student/Faculty Ratio

4O. Professional Licensure Exams - Undergraduate Programs

4P. Tuition Differential Fee

\section{Section 5 - Graduate Education}

TABLE 5A. Graduate Degree Program Changes in AY 2009-2010

5B. Graduate Degrees Awarded

5C. Graduate Degrees Awarded in Areas of Strategic Emphasis

5D. Professional Licensure Exams - Graduate Programs

\section{Section 6 - Research and Economic Development}

TABLE 6A. Research and Development

6B. Centers of Excellence

6C. State University Research Commercialization Assistance Grants

6D. 21st Century World Class Scholars Program 


\begin{tabular}{|c|c|c|c|c|c|c|c|}
\hline \multicolumn{8}{|c|}{ University of South Florida - Polytechnic 2011 Annual Report } \\
\hline \multicolumn{3}{|c|}{ Sites and Campuses } & \multicolumn{5}{|c|}{ Polytechnic Campus } \\
\hline Enrollments & Headcount & $\%$ & \multicolumn{3}{|c|}{ Degree Programs Offered (As of Spr. 2011) } & \multicolumn{2}{|c|}{$\begin{array}{r}\text { Carnegie Classification } \\
\end{array}$} \\
\hline Black & 144 & $11 \%$ & Baccalaureat & & \multirow{4}{*}{$\begin{array}{c}\text { Total } \\
\text { programs } \\
\text { reflected } \\
\text { at the } \\
\text { USF } \\
\text { System } \\
\text { level. }\end{array}$} & Graduate Instructional & Postbac-Prof/Ed: Postbaccalaureate professional \\
\hline Hispanic & 152 & $12 \%$ & Master's \& Speci & ist's & & Program: & (education dominant) \\
\hline White & 880 & $69 \%$ & Research Docto & & & Enrollment Profile: & HU: High undergraduate \\
\hline Other & 93 & $7 \%$ & \multicolumn{2}{|c|}{ Professional Doctorate } & & Undergraduate Profile: & PT4: Higher part-time four-year \\
\hline Full-Time & 500 & $39 \%$ & \multirow{2}{*}{ Faculty (Fall 2010) } & \multirow{2}{*}{$\begin{array}{l}\text { Full- } \\
\text { Time }\end{array}$} & \multirow{2}{*}{$\begin{array}{l}\text { Part- } \\
\text { Time }\end{array}$} & Size and Setting: & $\begin{array}{c}\text { VS4/NR: Very small four-year, primarily } \\
\text { nonresidential }\end{array}$ \\
\hline Part-Time & 769 & $61 \%$ & & & & \multirow{2}{*}{ Basic: } & \multirow{2}{*}{$\begin{array}{l}\text { Master's M: Master's Colleges and Universities } \\
\text { (medium programs) }\end{array}$} \\
\hline Undergraduate & 1,072 & $84 \%$ & TOTAL & 43 & 54 & & \\
\hline Graduate & 162 & $13 \%$ & Tenure/T. Track & 30 & 0 & Elective Classification: & $\mathrm{n} / \mathrm{a}$ \\
\hline
\end{tabular}

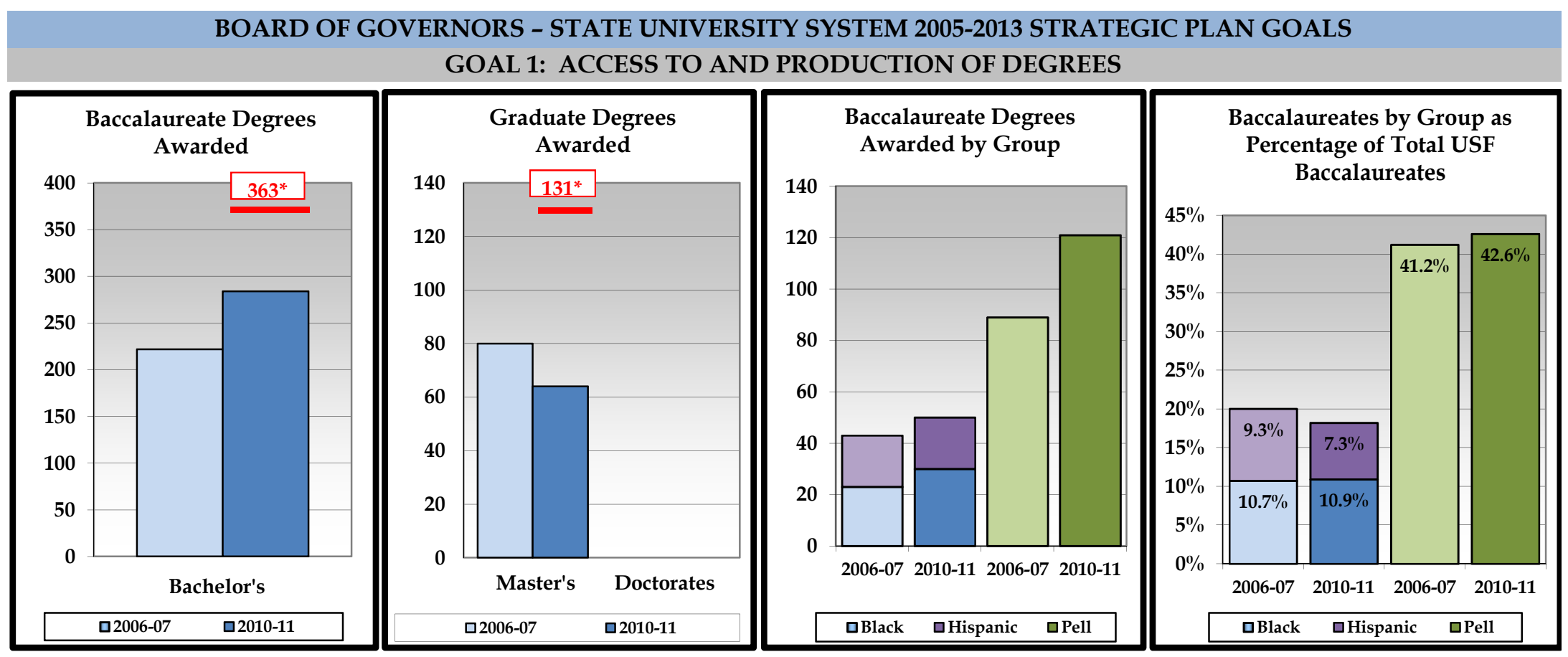




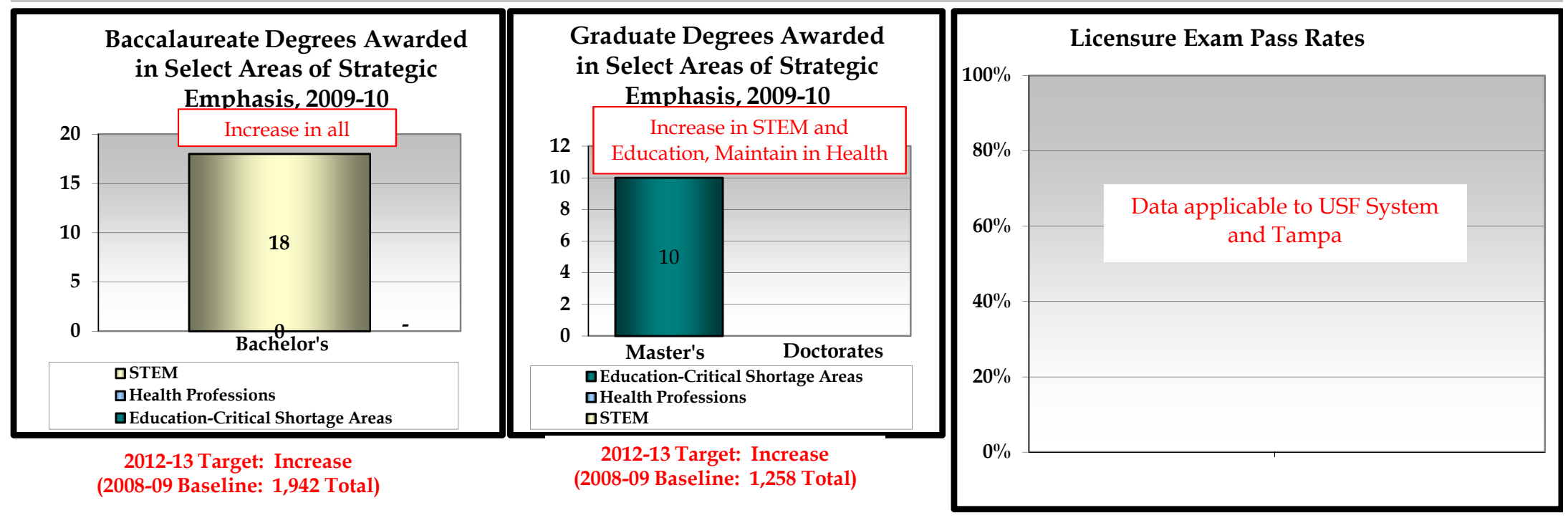

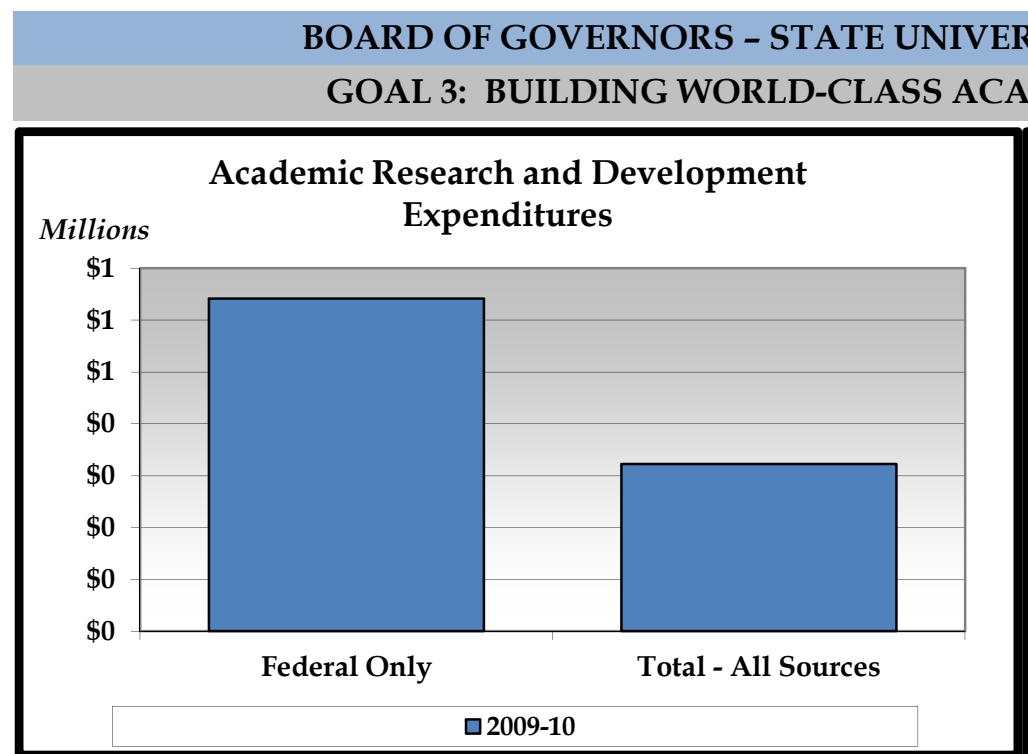

*2011-12 Targets for Research \& Development Expenditures.

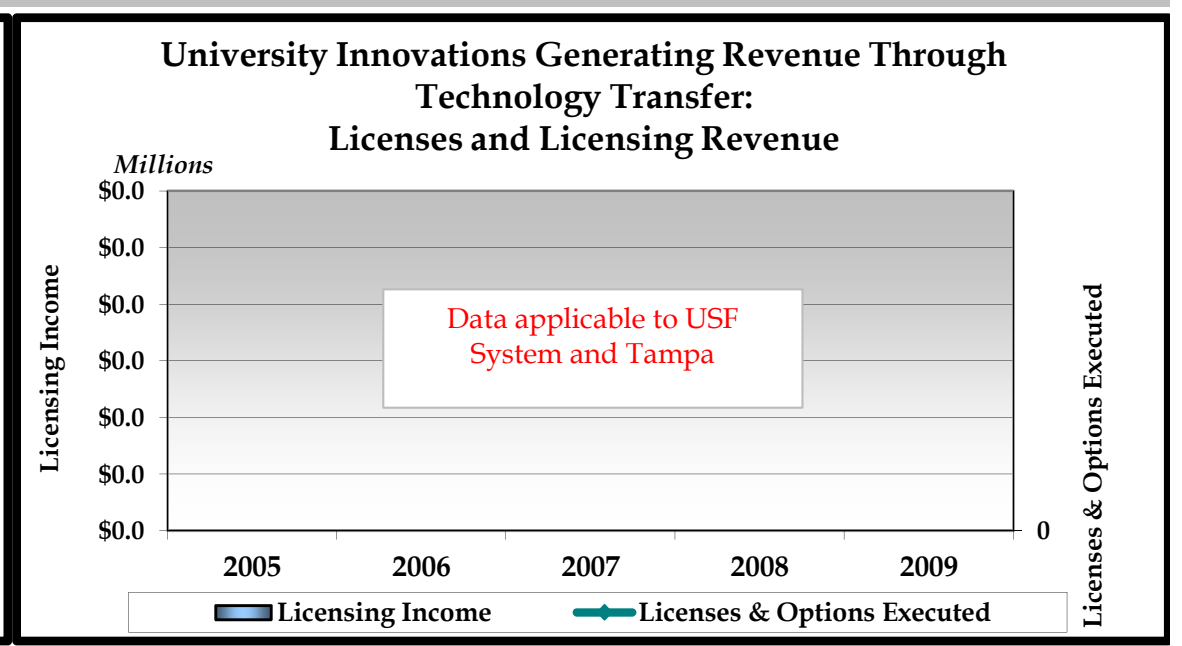

2011-12 Targets: Licenses - Increase (2008 Baseline $=23)$ Licensing Revenue - Increase (2008 Baseline $=\$ 2,099,712)$ 
RESOURCES, EFFICIENCIES, AND EFFECTIVENESS

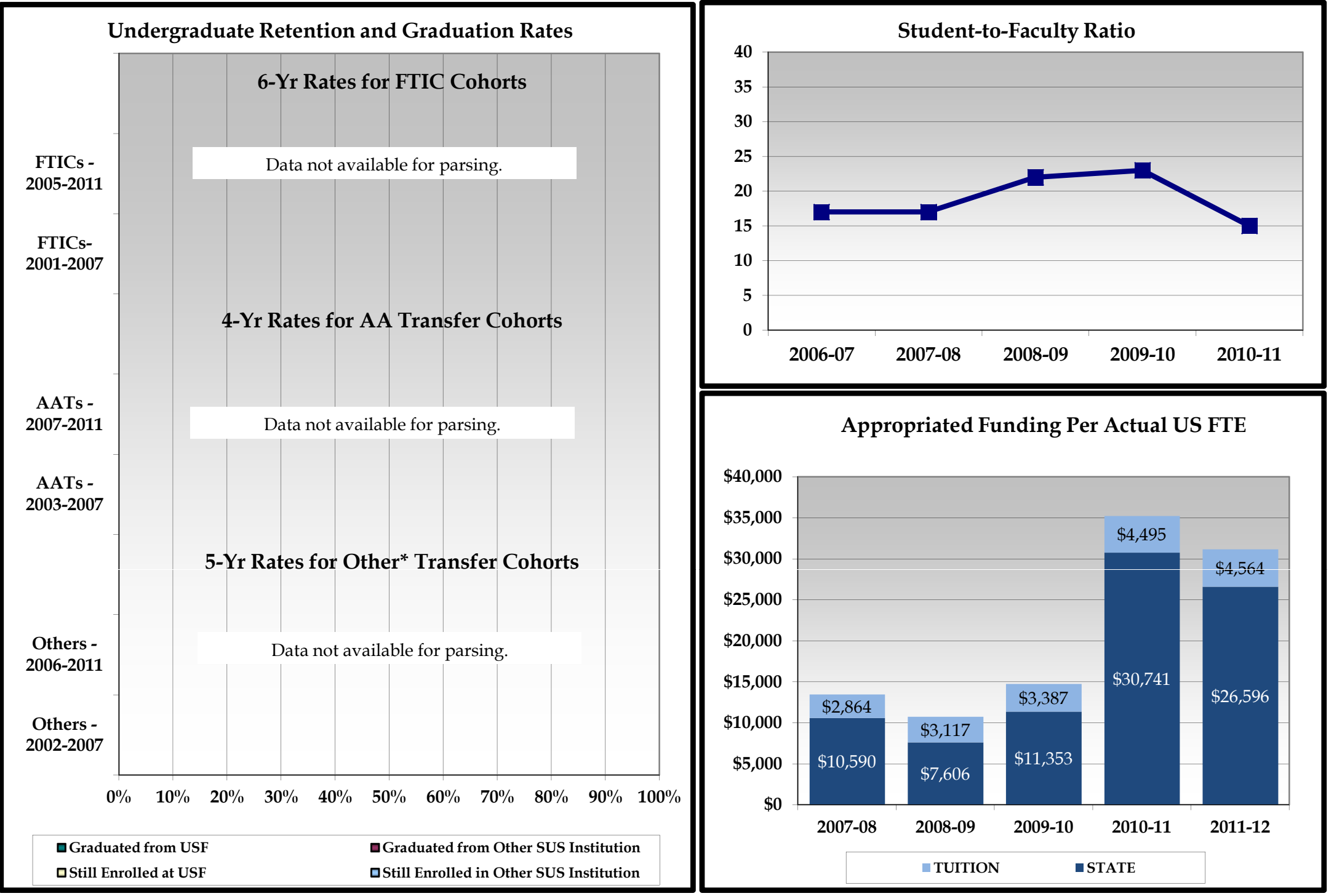

* The composition of "Other Transfer" cohorts may vary greatly by institution and by year.

TUITION is the appropriated budget authority, not the amount actually collected. Does not include non-instructional local fees.

**Graduation Rate from SAME Institution.

STATE includes General Revenues, Lottery and Other Trust funds (ie. Federal Stimulus for 2009-10 and 2010-11 only). 


\section{USF - POLYTECHNIC 2010-11 NARRATIVE REPORT}

\section{INTRODUCTION}

\section{Mission}

The University of South Florida Polytechnic is committed to excellence in interdisciplinary and applied learning; to the application of cutting-edge research and technology to real world needs; and to collaborative partnerships that support economic, social, and community development.

\section{Vision}

The University of South Florida Polytechnic will be a premier destination campus for applied learning, research and innovative technology. Our students and graduates will inspire and lead change, locally and internationally.

\section{Context}

Effective July 1, 2008, Florida Statute 1004.345 established The University of South Florida Polytechnic, a separate organizational and budget entity of The University of South Florida, intended to operate under separate accreditation from the Southern Association of Colleges and Schools Commission on Colleges.

In December 2010 USF Polytechnic submitted its application for initial accreditation by the Commission on Colleges of the Southern Association of Colleges and Schools (SACS). Review of the application was suspended in February 2011 while a substantive change prospectus was submitted by the University of South Florida, seeking approval from the Commission on Colleges to add lower-level courses and enrollment at USF Polytechnic, as approved by the USF Board of Trustees on September 20, 2009, and by the State University System of
Florida Board of Governors on September 24, 2009. An update to the prospectus in response to additional information requested by SACS was transmitted on June 1, 2011. Approval for offering lower level courses at USF Polytechnic, effective spring 2012, with the first freshman class to be admitted fall 2013, was transmitted by Dr. Belle Whelan, SACS President, to USF System President Judy Genshaft on July 8, 2011.

In August 2011 Regional Chancellor Dr. Marshall Goodman responded to a request from Board of Governors Chair, Ava Parker, to present an overview of the Polytechnic Model at the Board's Strategic Planning Committee meeting on September 25, 2011. On August 24, 2011, Dr. Belle Whelan transmitted to President Judy Genshaft notification that SACS would once again suspend review of the USF Polytechnic application pending clarification of the status of USF Polytechnic.

Following the presentation to the Board of Governors Strategic Planning Committee, Regional Chancellor Goodman was charged by State University System Chancellor Brogan to prepare a business plan for a new polytechnic university in Florida. The plan is scheduled for presentation to the Board of Governors on November 9, 2011.

SACS review of USF Polytechnic's application is still suspended.

\section{Developmental and Aspirational Peer Institutions} USF Polytechnic has selected three developmental peers:

- Arizona State University's Polytechnic Campus in Mesa, $\mathrm{AZ}$, is a public, suburban university established in 1996 as ASU East. In 2005 the campus name and mission were changed to ASU's Polytechnic Campus, serving more than 9,750 students in more than 40 undergraduate and master's degree programs in fall 2011. 
- Southern Polytechnic was founded in 1948 as a two-year division of Georgia Institute of Technology and first opened its doors as the Technical Institute in Chamblee, Georgia, with a staff of 12 and 116 students, all but 10 being World War II veterans.

In 1949, SPSU became the Southern Technical Institute and was recognized as a college-level school by the U.S.

Department of Education. Twelve years later, the college migrated to its present campus in Marietta, Georgia. In 1961, eight new buildings were built on 120 acres of land. SPSU became accredited as a four-year college in 1970, and was one of the last technical institutes in the nation to offer the bachelor of Engineering Technology degree. In 1979-1980 Southern Poly separated ties with Georgia Tech, and in the summer of 1980, SPSU officially became the 14 th senior college and the 33rd independent unit of the University System.

Southern Polytechnic now sits on more than 203 acres, is comprised of 65 buildings, and serves approximately 5,500 students, representing 36 states and 64 countries. Southern Poly educates students for leadership in an increasingly technological world. Students are prepared for their very first job after graduation, with the skills that make them highly marketable and successful. In fall 2010 Southern Poly served 5,064 undergraduate students and 693 graduate students.

- The University of Wisconsin Stout Campus in Menomonie, WI, is a public, rural university established in 1971 as a regional campus in the University of Wisconsin System. In 2007 UW-Stout was designated “Wisconsin's Polytechnic University" by the UW System Board of Regents with a mission as a "comprehensive, career-focused polytechnic where students, faculty and staff use applied learning, scientific theory and research to solve real-world problems, grow the state economy and serve society." UW Stout currently serves 9,339 students offering 60 degrees, primarily undergraduate and masters.

Three aspirational peers have also been selected:

- California Polytechnic State University in San Luis Obispo, CA, is a public, suburban university established in 1901. It serves approximately 18,360 students offering numerous polytechnic bachelor's, master's and doctoral degrees.

- Rensselaer Polytechnic Institute in Troy, NY is a private, urban university established in 1824 . It serves approximately 6,435 students offering bachelor's, master's and doctoral degrees in many of the science, technology, engineering, and mathematic areas.

- Virginia Tech in Blacksburg, VA is a public, rural university established in 1872. It serves approximately 31,000 students with a strong emphasis on polytechnic bachelor's, master's and doctoral degrees.

\section{BOARD OF GOVERNORS - STATE UNIVERSITY SYSTEM GOAL 1: ACCESS TO AND PRODUCTION OF DEGREES}

In AY 2010-2011 total undergraduate FTE (lower and upper levels) increased by $4.7 \%$ from 806 to 884 . Grad I FTE decreased by $9.6 \%$ from 104 to 94 during the same period.

The percentage of undergraduate students who applied for admission to USF Polytechnic, were accepted and then enrolled in courses increased from $72 \%$ to $74 \%$. The percentage of graduate students who applied for admission to USF Polytechnic, were accepted and then enrolled in courses increased from $72 \%$ to $78 \%$.

The number of bachelor's degrees awarded in the same time period increased from 254 to 286 . The percentage of baccalaureate degrees completed without excess credit hours 
remained stable at $65.7 \%$. Time to degree decreased from 2.91 years to 2.76 years. The mean undergraduate GPA increased from 2.99 to 3.05 .

The number of master's degrees awarded decreased from 78 to 64 . The number of master's degrees awarded in areas of strategic emphasis decreased from 11 to 10 . Time to degree increased from 1.72 years to 2.05 years. The mean graduate GPA increased from 3.78 to 3.79 .

In AY 2010-2011, the following strategies to increase student enrollment and retention were implemented:

- Completion of staffing of the Enrollment Management unit in admissions, recruitment and advising. Continuation of implementation and monitoring of a comprehensive enrollment management plan for marketing, recruitment, admissions, advising, retention and graduation of diverse and high quality students.

- Full implementation of Hobson's Communication Management program and DegreeWorks degree audit system.

- Increased comprehensive student life activities to include academic and technology extra- and co-curricular activities; social and community engagement opportunities; and personal, academic and career support services.

- Increased opportunities for student leadership, mentoring and learning community programs to contribute to student success and create a sense of belonging to USF Polytechnic.

- Implementation of Lakeland Collegiate High School pilot Pipeline Program and Promoting Academic Success for Elementary School Boys of Color Program through the USF Polytechnic Office of Multicultural Education and Engagement.
Completion of an initial General Education Curriculum for fall 2012, focusing on a narrow number of course offerings, aligned with the USF Polytechnic learning model and learning outcomes: Reasoning and Problem Solving, Communication, Diversity and World Perspective, Social Responsibility, Ethical Behavior, Application of Technology, Inquiry and Applied Research, Interdisciplinary Thinking, and Civic Engagement.

\section{BOARD OF GOVERNORS - STATE UNIVERSITY SYSTEM GOAL 2: MEETING STATEWIDE PROFESSIONAL AND WORKFORCE NEEDS}

USF Polytechnic Extended University expanded its program offerings for workforce professional development: GMAT Prep Course, Board 491 Clinical Supervision, English Language for Business, Florida Child Care Professional Credential, HR Practitioner's Certificate, P.E. Exam Prep, F.E. Exam Review, AutoCAD Training (Beginning, Intermediate and Advanced), Control Systems Certificate, SupplyPoint Proposal and Engineering Assistance Training, Non-profit Management Certificate, Project Management Certification Prep Course.

\section{BOARD OF GOVERNORS - STATE UNIVERSITY SYSTEM GOAL 3: BUILDING WORLD-CLASS ACADEMIC PROGRAMS AND RESEARCH CAPACITY}

\section{Academic Programs}

A 10-15 year program development plan was articulated with the goal of articulating an array of degree programs that would bring USF Polytechnic's degree array within the mean proportions of STEM, STEM-related Professions, and Liberal Arts fields in the established polytechnics and institute of technology studied since 2008. The degree array planned would 
accomplish that goal, shifting significantly from the program array carried over from USF Tampa to USF Polytechnic for initial SACS accreditation.

The Division of Innovation Management developed and implemented a mentoring component for the MBA Program and developed the program proposal for an interdisciplinary degree in Accounting and Financial Management.

The Division of Information Technology launched the M.S. in Information Technology program in fall 2011. Nearing completion and in early implementation is a joint, NSF-funded project with Polk State College (PSC) to produce advanced Linux systems administrators through a novel, dual-track articulated online curriculum. Students may attend PSC and earn either an A.S. or A.A. degree, and then proceed to USF Polytechnic, where they enter the BSAS/IT or BSIT program, as appropriate. The program emphasizes the higher-order thinking skills identified by industry advisory board members as needed for advanced systems administrators.

The Division of Education increased enrollment of minority and Hispanic first-generation college students in the Early Childhood Development Concentration of the B.S. in Applied Science. The Division has also launched a comprehensive program of STEM initiatives in Pre-K through 12 schools, including workshops and course work offered through TIES, the Teacher Institute for Excellence in STEM, funded through a USF Polytechnic Challenge Grant.

The Division of Social Sciences developed and submitted to the USF System for approval, pre-proposals for four new academic degree programs: BS in Law Enforcement Science and Technology, BS in Biological Sciences, a combined BS/MS in Nutrition and Dietetics, and a BS in Digital Design and Technology.
Students enrolled in ENC 3246, Communications for Engineers, with Dr. Cynthia Patterson, were featured in Mosaic's January, 2011 newsletter for their research at Mosaic's Information Technology department on the workplace ethnography project.

\section{Research Capacity}

In 2010-2011 total external awards were $\$ 1,885,880$ as compared to $\$ 241,381$ in 2009-2010. In addition, seven proposals were submitted

Totaling $\$ 1,554,342$.

The Accelerated Academic STEM Pipeline Project was funded by the

Helios Foundation at $\$ 950,000$.

The Division of Engineering pursued multiple grants in the areas of RFID, open-source engineering software, biofuels, renewable energy, and sustainability and environmental systems engineering.

The Association of Computing Machinery, the premier academic professional organization in computing, announced that it will hold the annual international conference of the Special Interest Group in IT Education (SIGITE) at USF Polytechnic in 2013.

A new Cyber-Forensics Laboratory will provide students and researchers capabilities to study and eventually investigate criminal activity related to computer use.

In 2010-2011 16 new faculty were hired, approximately 70\% from STEM or STEM-related professions fields. 


\section{BOARD OF GOVERNORS - STATE UNIVERSITY SYSTEM GOAL 4: MEETING COMMUNITY NEEDS AND FULFILLING UNIQUE INSTITUTIONAL RESPONSIBILITIES}

\section{Economic Development}

USF Polytechnic's Office of Experiential and Applied Learning and Blue Sky Center for Incubation Innovation established two community outreach centers in Sebring and Wauchula. The outreach centers provide opportunities for middle and high school students to learn about USF Polytechnic and receive general college mentoring. In addition, local businesses and community members have access to economic development and entrepreneurship information sessions.

\section{International Partnerships}

International cooperative partnerships for education and faculty research exchange are also coordinated through Extended University. Partnership agreements have been developed with the following education institutions and government agencies:

- Avans University of Applied Sciences, the Netherlands, 2010-2015

- EUROMED Management Ecole de Management Marseille, France, 2010-2015

- Escuela Americana, El Salvador, 2009-2012

- FEPADE - Fundacion Empresarial Para El Desarrollo Educative, El Salvador, 2009-2012

- L'Institute Polytechnique de Grenoble, France, 2010-2015

- Multimedia Incubator Belle de Mai, France, 2010-2013

- University of Nice - Sophia Antipolis, France, 2010-2015

- University of Provence Aix-Marseille, France, 2009-2014

- Turku University of Applied Sciences, Finland, 2009-2012

- Vidyalankar Dnyanapeeth Trust's Vidyalandkar School of Informational Technology, India, 2010-2015

\section{Community Education}

The USF Polytechnic Summer Gifted and Talented Program is coordinated through Extended University. In summer 2011 the program featured four high-tech, high-engagement learning experiences: CrimeLab, Hot2Bot, Sci-Fi High and Extreme Green Adventure. One hundred fifty-four middle school students attended the program, with $65 \%$ receiving donorgranted scholarships.

USF Polytechnic's MasterMinds Program is a tutoring program designed for students in grades 1 through 8 who are experiencing reading and/or writing difficulties or who need additional support. Tutoring is conducted in a one-on-one setting focusing on vocabulary, spelling and writing skills. Tutors are master's degree students in Reading Education who also receive mentoring from faculty.

USF Poly RoboBattle is a FIRST (For Inspiration and Recognition of Science and Technology) Tech Challenge regional qualifying competition featuring 15-18 high school teams. This season's qualifying event will take place Feb 4, 2012. The 2011 qualifier took place on January 29, 2011. The FIRST Tech Challenge (FTC) is a mid-level robotics competition for high school students.

Several faculty initiatives have also been completed in partnership with community agencies/businesses:

- Partnership with and a grant from the Watson Clinic to study cognitive impairment resulting from breast cancer.

- Partnership with Florida Presbyterian Homes on several lines of research in the application of Clinical Nutrition to well care, effects on cognitive impairment and 
dementia, health promotion, development and implement a safety and crime prevention protocol for residents.

- Partnership with the Lakeland Collegiate High School on an admissions pipeline.

\section{PROGRESS ON PRIMARY INSTITUTIONAL GOALS AND METRICS AS OUTLINED IN THE UNIVERSITY 2009-2010 WORK PLAN}

Increase the number of baccalaureate degrees awarded. The number of bachelor's degrees awarded in the same time period increased from 254 to 286 . The percentage of baccalaureate degrees completed without excess credit hours remained stable at $65.7 \%$.

Increase the number of master's degrees awarded. The number of master's degrees awarded decreased from 78 to 64 . The implementation of the M.S. in Information Technology in fall 2011 as well as the completion of the first cohort of MBA students should affect this goal in the future.

\section{Increase the number of baccalaureate degrees awarded in} STEM fields. The number of baccalaureate degrees awarded in STEM fields remained stable. Goal 3 of the USFP Strategic Plan states: Expand and create academic programs that focus on applied learning, applied research, applied technology, and interdisciplinary approaches in a polytechnic model. Develop and implement new degree programs in five areas of distinction; applied health sciences; mathematics and science education; business and entrepreneurship; manufacturing engineering and technology; and information technologies (all STEM fields). As we develop our polytechnic model, all processes and procedures are focused on this commitment.

\section{ADDITIONAL INFORMATION ON QUALITY, RESOURCES, EFFICIENCIES AND EFFECTIVENESS}

USF System Services. The USF System provides central services through several offices: 1) Audit \& Compliance, 2) Diversity \& Equal Opportunity, 3) General Counsel, 4) Government Relations, and 5) Special Events and Ceremonies. An annual cost allocation for services from these offices is distributed to each campus in the USF System to ensure consistency in implementation of USF System regulations and policies and to avoid duplication of the system-wide central services.

Other USF Tampa offices also provide services to all campuses within the USF System, for example: 1) Enterprise business systems, e.g., FAST, GEMS, FAIR for student, employee and financial data; 2) purchasing and accounting; 3) Research and Innovation for research compliance and grant/contract proposals, awards and management; 3) USF Libraries; 4) Financial Aid; 5) International Affairs; 6) Decision Support; 7) University Advancement; 8) Information Technology; 9) Communications and Marketing. Again, an annual cost allocation for services from these offices is distributed to each campus in the USF System.

Campus-specific Efforts. Over the last five years USF Polytechnic saved approximately $\$ 300,000$ in telecommunication costs with the implementation of a high function, integrated phone system. USF Polytechnic has created additional recurring savings by moving toward convergent networks integrating operational systems (i.e., Video, Voice, Data, Security cameras and keycard access systems) into the infrastructure of the network removing the necessity to have separate cabling and additional equipment for each service. 


\section{ADDITIONAL RESOURCES}

Links to the following resources are provided:

- USF Polytechnic Strategic Plan 2007-2012

(http:// www.poly.usf.edu/AboutUs/StrategicPlan.html)

- USF Polytechnic Voluntary System of Accountability

College

Portrait of Undergraduate Education

- Common Data Set

- College Navigator

- USF Polytechnic Institutional Research, Effectiveness and

Planning 
Section 1 - Financial Resources

\begin{tabular}{|c|c|c|c|c|c|}
\hline & $\begin{array}{l}2007-08 \\
\text { Actual }\end{array}$ & $\begin{array}{l}\text { 2008-09 } \\
\text { Actual }\end{array}$ & $\begin{array}{r}\text { 2009-10 } \\
\text { Actual }\end{array}$ & $\begin{array}{r}\text { 2010-11 } \\
\text { Actual } \\
\end{array}$ & $\begin{array}{c}2011-12 \\
\text { Estimates }\end{array}$ \\
\hline $\begin{array}{l}\text { Recurring } \\
\text { State Funds } \\
\text { (GR \& Lottery) }\end{array}$ & $\$ 10,053,299$ & $\$ 9,394,081$ & $\$ 13,025,886$ & $\$ 28,162,037$ & $\$ 27,653,585$ \\
\hline $\begin{array}{l}\text { Non-Recurring } \\
\text { State Funds } \\
\text { (GR \& Lottery) }\end{array}$ & $\$ 102,875$ & $\$ 98,300$ & $\$ 59,794$ & $\$ 778,980$ & $\$ 185,765$ \\
\hline $\begin{array}{l}\text { Tuition } \\
\text { (Resident \& Non-Resident) }\end{array}$ & $\$ 2,743,529$ & $\$ 3,787,462$ & $\$ 3,901,586$ & $\$ 4,181,180$ & $\$ 5,405,443$ \\
\hline Tuition Differential Fee & $\$ 0$ & $\$ 0$ & $\$ 144,450$ & $\$ 354,468$ & $\$ 569,837$ \\
\hline $\begin{array}{l}\text { Other Revenues } \\
\text { (Includes Misc. Fees \& Fines) }\end{array}$ & $\$ 3,109$ & $\$ 2,332$ & $\$ 69,210$ & $\$ 43,401$ & $\$ 63,543$ \\
\hline $\begin{array}{l}\text { Phosphate Research } \\
\text { Trust Fund }\end{array}$ & $\$ 0$ & $\$ 0$ & $\$ 0$ & $\$ 7,330,654$ & $\$ 7,334,170$ \\
\hline Federal Stimulus Funds & $\$ 0$ & $\$ 0$ & $\$ 708,656$ & $\$ 678,080$ & $\$ 0$ \\
\hline TOTAL & $\$ 12,902,812$ & $\$ 13,282,175$ & $\$ 17,909,582$ & $\$ 41,528,800$ & $\$ 41,212,343$ \\
\hline
\end{tabular}

TABLE 1B. University Education and General Expenditures

\begin{tabular}{|c|c|c|c|c|c|}
\hline & $\begin{array}{l}\text { 2007-08 } \\
\text { Actual }\end{array}$ & $\begin{array}{c}\text { 2008-09 } \\
\text { Actual }\end{array}$ & $\begin{array}{c}\text { 2009-10 } \\
\text { Actual }\end{array}$ & $\begin{array}{r}2010-11 \\
\text { Actual }\end{array}$ & $\begin{array}{c}2011-12 \\
\text { Estimates }\end{array}$ \\
\hline Instruction/Research & $\$ 9,420,645$ & $\$ 7,041,399$ & $\$ 7,872,850$ & $\$ 16,685,478$ & $\$ 30,602,611$ \\
\hline $\begin{array}{l}\text { Institutes and Research } \\
\text { Centers }\end{array}$ & $\$ 0$ & $\$ 0$ & $\$ 0$ & $\$ 0$ & $\$ 0$ \\
\hline PO\&M & $\$ 187,904$ & $\$ 156,064$ & $\$ 180,911$ & $\$ 186,909$ & $\$ 173,763$ \\
\hline $\begin{array}{l}\text { Administration and } \\
\text { Support Services }\end{array}$ & $\$ 1,444,066$ & $\$ 2,309,412$ & $\$ 2,150,419$ & $\$ 2,403,961$ & $\$ 9,183,619$ \\
\hline Radio/TV & $\$ 0$ & $\$ 0$ & $\$ 0$ & $\$ 0$ & $\$ 0$ \\
\hline Library/Audio Visual & $\$ 237,544$ & $\$ 415,527$ & $\$ 529,480$ & $\$ 612,424$ & $\$ 479,587$ \\
\hline Museums and Galleries & $\$ 0$ & $\$ 0$ & $\$ 0$ & $\$ 0$ & $\$ 0$ \\
\hline Agricultural Extension & $\$ 0$ & $\$ 0$ & $\$ 0$ & $\$ 0$ & $\$ 0$ \\
\hline Student Services & $\$ 779,724$ & $\$ 755,885$ & $\$ 805,268$ & $\$ 904,204$ & $\$ 762,013$ \\
\hline Intercollegiate Athletics & $\$ 0$ & $\$ 0$ & $\$ 0$ & $\$ 0$ & $\$ 0$ \\
\hline $\begin{array}{l}\text { Academic Infrastructure } \\
\text { Support Organization }\end{array}$ & $\$ 0$ & $\$ 0$ & $\$ 0$ & $\$ 0$ & $\$ 0$ \\
\hline TOTAL & $\$ 12,069,883$ & $\$ 10,678,287$ & $\$ 11,538,928$ & $\$ 20,792,976$ & $\$ 41,201,593$ \\
\hline
\end{tabular}
\begin{tabular}{|l|l|l|l|l|l|}
\hline TOTAL & $\mathbf{\$ 1 2 , 0 6 9 , 8 8 3}$ & $\mathbf{\$ 1 0 , 6 7 8 , 2 8 7}$ & $\mathbf{\$ 1 1 , 5 3 8 , 9 2 8}$ & $\mathbf{\$ 2 0 , 7 9 2 , 9 7 6}$ & $\mathbf{\$ 4 1 , 2 0 1 , 5 9 3}$ \\
\hline
\end{tabular} The table reports the actual and estimated amount of expenditures from revenues appropriated by the Legislature for each fiscal year. The expenditures are classified by Program Component (i.e.,

Instruction/Research, PO\&M, Administration, etc.) for activities directly related to instruction, research and public service. The table does not include expenditures classified as non-operating expenditures (i.e., to service asset-related debts), and therefore excludes a small portion of the amount appropriated each year by the Legislature. Also, the table does not include expenditures from funds carried forward from previous years.

USF Polytechnic 2011 Annual Report
Section 1 - Financial Resources (continued)

\begin{tabular}{|c|c|c|c|c|c|}
\hline & $\begin{array}{c}2007-08 \\
\text { Actual } \\
\end{array}$ & $\begin{array}{c}\text { 2008-09 } \\
\text { Actual }\end{array}$ & $\begin{array}{c}\text { 2009-10 } \\
\text { Actual } \\
\end{array}$ & $\begin{array}{c}2010-11 \\
\text { Actual } \\
\end{array}$ & $\begin{array}{c}2011-12 \\
\text { Estimates }\end{array}$ \\
\hline \multicolumn{6}{|c|}{ Appropriated Funding per FTE } \\
\hline General Revenue per FTE & $\$ 10,554$ & $\$ 7,530$ & $\$ 10,581$ & $\$ 23,712$ & $\$ 20,537$ \\
\hline Lottery Funds per FTE & $\$ 36$ & $\$ 276$ & $\$ 189$ & $\$ 366$ & $\$ 505$ \\
\hline Tuition \& Fees per FTE & $\$ 2,864$ & $\$ 3,117$ & $\$ 3,387$ & $\$ 4,495$ & $\$ 4,564$ \\
\hline Other Trust Funds per FTE & $\$ 0$ & $\$ 0$ & $\$ 583$ & $\$ 6,663$ & $\$ 5,544$ \\
\hline Total per FTE & $\$ 13,454$ & $\$ 10,923$ & $\$ 14,740$ & $\$ 35,235$ & $\$ 31,151$ \\
\hline \multicolumn{6}{|l|}{ Actual Funding per FTE } \\
\hline Tuition \& Fees per FTE & $\$ 2,864$ & $\$ 3,117$ & $\$ 3,387$ & $\$ 3,810$ & $\$ 4,564$ \\
\hline Total per FTE & $\$ 13,454$ & $\$ 10,923$ & $\$ 14,740$ & $\$ 34,550$ & $\$ 31,151$ \\
\hline \multicolumn{6}{|c|}{$\begin{array}{l}\text { Notes: (1) FTE is based on actual FTE, not funded FTE; (2) does not include Health-Science Center funds } \\
\text { or FTE; (3) FTE for these metrics uses the standard IPEDS definition of FTE, equal to } 30 \text { credit hours for } \\
\text { undergraduates and } 24 \text { for graduates; and (4) actual funding per student is based on actual tuition and } \\
\text { E\&G fees (does not include local fees) collected. }\end{array}$} \\
\hline
\end{tabular}

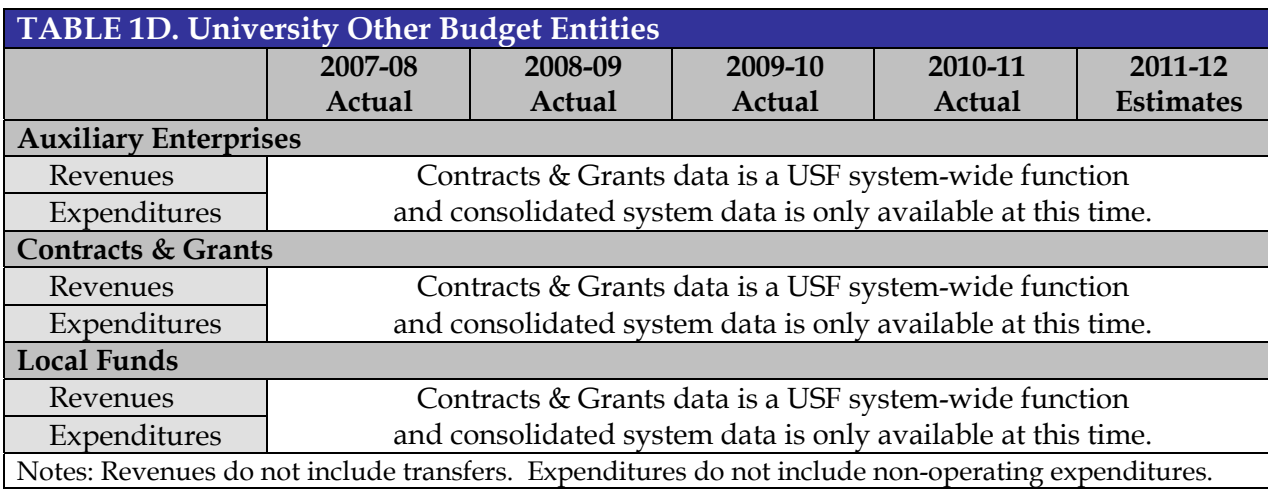

\begin{tabular}{|c|c|c|c|c|c|}
\hline \multicolumn{7}{|c|}{ TABLE 1E. University Total Revenues and Expenditures } \\
\hline & $\begin{array}{c}2007-08 \\
\text { Actual }\end{array}$ & $\begin{array}{c}2008-09 \\
\text { Actual }\end{array}$ & $\begin{array}{c}2009-10 \\
\text { Actual }\end{array}$ & $\begin{array}{c}2010-11 \\
\text { Actual }\end{array}$ & $\begin{array}{c}\mathbf{2 0 1 1 - 1 2} \\
\text { Estimates }\end{array}$ \\
\hline $\begin{array}{c}\text { Total } \\
\text { Revenues }\end{array}$ & $\$ 12,902,812$ & $\$ 13,282,175$ & $\$ 17,909,582$ & $\$ 41,528,800$ & $\$ 41,221,343$ \\
\hline $\begin{array}{c}\text { Total } \\
\text { Expenditures }\end{array}$ & $\$ 12,069,883$ & $\$ 10,678,287$ & $\$ 11,538,928$ & $\$ 20,792,976$ & $\$ 41,201,593$ \\
\hline
\end{tabular}


Section 1 - Financial Resources (continued)

\section{TABLE 1F. Voluntary Support of Higher Education}

\begin{tabular}{|l|l|l|l|l|}
\hline $2005-06$ & $2006-07$ & $2007-08$ & $2008-09$ & $2009-10$ \\
\hline
\end{tabular}

Endowment Market

Value (Thousand \$)

Annual Gifts

Received (\$)

Percentage of

Graduates Who are

Alumni Donors

\begin{tabular}{|l|c|c|}
\hline TABLE 1G. University Federal Stimulus Dollars (ARRA) \\
\hline Jobs Saved/Created & $\begin{array}{r}\mathbf{2 0 0 9 - 1 0} \\
\text { Actual }\end{array}$ & $\begin{array}{r}\mathbf{2 0 1 0 - 1 1} \\
\text { Actual }\end{array}$ \\
\hline Scholarships & $\$ 708,656$ & $\$ 678,080$ \\
\hline Library Resources & $\$ 0$ & $\$ 0$ \\
\hline Building Repairs/Alterations & $\$ 0$ & $\$ 0$ \\
\hline Motor Vehicles & $\$ 0$ & $\$ 0$ \\
\hline Printing & $\$ 0$ & $\$ 0$ \\
\hline Furniture \& Equipment & $\$ 0$ & $\$ 0$ \\
\hline Information Technology Equipment & $\$ 0$ & $\$ 0$ \\
\hline Financial Aid to Medical Students & $\$ 0$ & $\$ 0$ \\
\hline Other & $\$ 0$ & $\$ 0$ \\
\hline TOTAL & $\$ 0$ & $\$ 678,080$ \\
\hline
\end{tabular}

\section{Section 2 - Personnel}

\section{TABLE 2A. Personnel Headcount}

\begin{tabular}{|c|c|c|c|c|c|c|c|c|c|c|}
\hline & \multicolumn{2}{|c|}{ Fall 2006} & \multicolumn{2}{|c|}{ Fall 2007} & \multicolumn{2}{|c|}{ Fall 2008} & \multicolumn{2}{|c|}{ Fall 2009} & \multicolumn{2}{|c|}{ Fall 2010} \\
\hline & $\begin{array}{l}\text { Full- } \\
\text { Time }\end{array}$ & $\begin{array}{l}\text { Part- } \\
\text { Time }\end{array}$ & $\begin{array}{l}\text { Full- } \\
\text { Time }\end{array}$ & $\begin{array}{l}\text { Part- } \\
\text { Time }\end{array}$ & $\begin{array}{l}\text { Full- } \\
\text { Time }\end{array}$ & $\begin{array}{l}\text { Part- } \\
\text { Time }\end{array}$ & $\begin{array}{l}\text { Full- } \\
\text { Time }\end{array}$ & $\begin{array}{l}\text { Part- } \\
\text { Time }\end{array}$ & $\begin{array}{l}\text { Full- } \\
\text { Time }\end{array}$ & $\begin{array}{l}\text { Part- } \\
\text { Time }\end{array}$ \\
\hline $\begin{array}{c}\text { Total Tenure/ } \\
\text { Tenure-track } \\
\text { Faculty }\end{array}$ & 22 & 0 & 23 & 0 & 19 & 0 & 19 & 0 & 30 & 0 \\
\hline $\begin{array}{l}\text { Total Non- } \\
\text { Tenure Track } \\
\text { Faculty }\end{array}$ & 13 & 3 & 14 & 2 & 12 & 6 & 11 & 5 & 13 & 54 \\
\hline $\begin{array}{c}\text { Instructors } \\
\text { Without Faculty } \\
\text { Status } \\
\end{array}$ & 0 & 0 & 0 & 0 & 0 & 0 & 0 & 0 & 0 & 0 \\
\hline $\begin{array}{c}\text { Total Graduate } \\
\text { Assistants/ } \\
\text { Associates }\end{array}$ & 0 & 5 & 0 & 4 & 0 & 2 & 0 & 3 & 0 & 1 \\
\hline $\begin{array}{c}\text { Total Executive/ } \\
\text { Administrative/ } \\
\text { Managerial }\end{array}$ & 17 & 0 & 22 & 0 & 18 & 0 & 18 & 0 & 27 & 0 \\
\hline $\begin{array}{c}\text { Total Other } \\
\text { Professional }\end{array}$ & 24 & 1 & 25 & 0 & 18 & 0 & 21 & 8 & 24 & 6 \\
\hline $\begin{array}{c}\text { Total Non- } \\
\text { Professional }\end{array}$ & 15 & 0 & 20 & 0 & 21 & 0 & 19 & 33 & 23 & 61 \\
\hline TOTAL & \multicolumn{2}{|c|}{100} & \multicolumn{2}{|c|}{110} & \multicolumn{2}{|c|}{96} & \multicolumn{2}{|c|}{137} & \multicolumn{2}{|c|}{239} \\
\hline
\end{tabular}


Section 3 - Enrollment

\section{TABLE 3A. University Full-Time Enrollment (FTE)} 2009-10

\begin{tabular}{|c|c|c|c|c|c|c|}
\hline & Funded & Actual & Funded & Actual & Funded & Estimated \\
\hline \multicolumn{7}{|c|}{ FLORIDA RESIDENTS } \\
\hline Lower & 0 & 51 & 0 & 56 & 0 & 93 \\
\hline Upper & 494 & 748 & 494 & 741 & 494 & 787 \\
\hline Grad I & 103 & 104 & 103 & 94 & 103 & 102 \\
\hline Grad II & 0 & 1 & 0 & 0 & 0 & 0 \\
\hline Total & $\mathbf{5 9 7}$ & $\mathbf{9 0 4}$ & $\mathbf{5 9 7}$ & $\mathbf{8 9 1}$ & $\mathbf{5 9 7}$ & $\mathbf{9 8 2}$ \\
\hline
\end{tabular}

\section{NON-FLORIDA RESIDENTS}

\begin{tabular}{|l|c|c|c|c|c|c|}
\hline Lower & & 1 & & 1 & & 1 \\
\hline Upper & & 7 & & 9 & & 10 \\
\hline Grad I & & 0 & & 0 & & 0 \\
\hline Grad II & & 0 & & 0 & & 0 \\
\hline Total & $\mathbf{0}$ & $\mathbf{8}$ & $\mathbf{0}$ & $\mathbf{1 0}$ & $\mathbf{0}$ & $\mathbf{1 1}$ \\
\hline
\end{tabular}

\section{Total}

\section{TOTAL FTE}

\begin{tabular}{|l|c|c|c|c|c|c|}
\hline Lower & 0 & 52 & 0 & 57 & 0 & 94 \\
\hline Upper & 494 & 754 & 494 & 750 & 494 & 796 \\
\hline Grad I & 103 & 104 & 103 & 94 & 103 & 103 \\
\hline Grad II & 0 & 1 & 0 & 0 & 0 & 0 \\
\hline $\begin{array}{l}\text { Total FTE } \\
\text { (FL Definition) }\end{array}$ & $\mathbf{5 9 7}$ & $\mathbf{9 1 1}$ & $\mathbf{5 9 7}$ & $\mathbf{9 0 1}$ & $\mathbf{5 9 7}$ & $\mathbf{9 9 2}$ \\
\hline $\begin{array}{l}\text { Total FTE } \\
\text { (US Definition) }\end{array}$ & $\mathbf{7 9 6}$ & $\mathbf{1 , 2 1 5}$ & $\mathbf{7 9 6}$ & $\mathbf{1 , 2 0 2}$ & $\mathbf{7 9 6}$ & $\mathbf{1 , 3 2 3}$ \\
\hline
\end{tabular}
(US Definition)

Notes: Florida definitions of FTE (Undergraduate FTE $=40$ and Graduate FTE $=32$ credit hours per FTE) are used for all items except the row named Total FTE (US Definition), which is based on an

Undergraduate FTE $=30$ and Graduate FTE $=24$ credit hours .

\section{Section 3 - Enrollment (Continued)}

\section{TABLE 3B. Enrollment by Location}

$$
\text { 2009-10 }
$$

MAIN CAMPUS

$$
\text { Actual }
$$

Actual

Estimated

\begin{tabular}{|c|c|c|}
\hline MAIN CAMPUS & 15 & \\
\hline Lower & 381 & \\
\hline Upper & 47 & \\
\hline Grad I & 0 & \\
\hline Grad II & $\mathbf{4 4 3}$ & \\
\hline TOTAL & & $\mathbf{4}$ \\
\hline
\end{tabular}

$$
\text { TOTAL }
$$

\begin{tabular}{|c|c|}
\hline 15 & 50 \\
\hline 366 & 391 \\
\hline 47 & 60 \\
\hline 0 & 0 \\
\hline 428 & $\mathbf{5 0 1}$ \\
\hline
\end{tabular}

\section{VIRTUAL/DISTANCE LEARNING}

For the sum of current or planned State-fundable FTE enrollments not served at a physical location.

\begin{tabular}{|c|c|c|c|}
\hline Lower & 37 & 42 & 44 \\
\hline Upper & 373 & 385 & 405 \\
\hline Grad I & 58 & 47 & 42 \\
\hline Grad II & 0 & 0 & 0 \\
\hline TOTAL & $\mathbf{4 6 8}$ & $\mathbf{4 7 4}$ & $\mathbf{4 9 2}$ \\
\hline
\end{tabular}

Note: The FTE reported in this table are more than the total in table $3 \mathrm{~A}$ (which does not include HSC FTE). Estimated figures-actual enrollment to be finalized in Spring 2012. 
Section 4 - Undergraduate Education

\begin{tabular}{|c|c|c|c|c|c|}
\hline Title of Program & $\begin{array}{c}\text { Six-digit } \\
\text { CIP } \\
\text { Code }\end{array}$ & $\begin{array}{l}\text { Degree } \\
\text { Level }\end{array}$ & $\begin{array}{l}\text { Date of } \\
\text { UBOT } \\
\text { Action }\end{array}$ & $\begin{array}{c}\text { Starting } \\
\text { or Ending } \\
\text { Term }\end{array}$ & Comments \\
\hline \multicolumn{6}{|l|}{ New Programs } \\
\hline \multicolumn{6}{|l|}{ N/A } \\
\hline \multicolumn{6}{|l|}{ Terminated Programs } \\
\hline \multicolumn{6}{|l|}{ N/A } \\
\hline & & & & & \\
\hline \multicolumn{6}{|l|}{ Inactive Programs } \\
\hline \multicolumn{6}{|l|}{$\mathrm{N} / \mathrm{A}$} \\
\hline \multicolumn{6}{|c|}{ New Programs Considered By University But Not Approved } \\
\hline \multicolumn{6}{|c|}{$\mathrm{N} / \mathrm{A}$} \\
\hline \multicolumn{6}{|c|}{$\begin{array}{l}\text { Note: This table does not include new majors or concentrations added under an existing degree program } \\
\text { CIP Code. This table reports the program changes between May 5, } 2010 \text { and May 4, 2011. New } \\
\text { Programs are proposed new degree programs that have been completely through the approval process } \\
\text { at the university and, if appropriate, the Board of Governors. Terminated Programs are degree } \\
\text { programs for which the entire CIP Code has been terminated and removed from the university's } \\
\text { inventory of degree programs. Inactive Programs are degree programs for which enrollments have been } \\
\text { temporarily suspended for the entire CIP Code, but the program CIP Code has not been terminated. }\end{array}$} \\
\hline \multicolumn{6}{|c|}{ TABLE 4B. First-Year Persistence Rates } \\
\hline Term of Entry & Fall 2005 & Fall 2006 & Fall 2007 & Fall 2008 & $\begin{array}{l}\text { Fall } 2009 \\
\text { Preliminary }\end{array}$ \\
\hline $\begin{array}{c}\text { Cohort Size } \\
\text { Full-time FTIC }\end{array}$ & \multicolumn{5}{|c|}{ N/A; No FTICs } \\
\hline \multicolumn{6}{|l|}{ From Same University } \\
\hline$\%$ Still Enrolled & \multicolumn{5}{|c|}{ N/A; No FTICs } \\
\hline
\end{tabular}

TABLE 4C. Federal Definition - Undergraduate Progression and Graduation Rates for

Full-Time First-Time-in-College (FTIC) Students

\begin{tabular}{|l|c|c|c|c|c|}
\hline $\begin{array}{c}\text { Term of Entry } \\
\text { Cohort Size } \\
\text { Full-time FTIC }\end{array}$ & Fall 2001 & Fall 2002 & Fall 2003 & Fall 2004 & $\begin{array}{c}\text { Fall 2005 } \\
\text { Preliminary }\end{array}$ \\
\hline $\begin{array}{l}\text { 6- - Year Rates } \\
\text { From Same University } \\
\text { \% Graduated }\end{array}$ \\
$\begin{array}{l}\text { \% Still Enrolled } \\
\text { \% Success Rate }\end{array}$ \\
\hline Notes: (1) Cohorts are based on undergraduate students who enter the institution in the Fall term (or \\
\hline
\end{tabular}

USF Polytechnic 2011 Annual Report
TABLE 4C. Federal Definition - Undergraduate Progression and Graduation Rates for

Full-Time First-Time-in-College (FTIC) Students

Summer term and continue into the Fall term); (2) Success Rate measures the percentage of an initial

cohort of students who have either graduated or are still enrolled; (3) since degrees can be awarded after the last semester of coursework, the most recent year of data in this table provides preliminary graduation rate data that may change with the addition of "late degrees". Late degrees reported in conjunction with the IPEDS Graduation Rate Survey due in mid-April will be reflected in the following year.

TABLE 4C. Federal Definition - Undergraduate Progression and Graduation Rates for

Full-Time First-Time-in-College (FTIC) Students

\begin{tabular}{|c|c|c|c|c|c|}
\hline Term of Entry & Fall 2001 & Fall 2002 & Fall 2003 & Fall 2004 & $\begin{array}{c}\text { Fall } 2005 \\
\text { Preliminary }\end{array}$ \\
\hline $\begin{array}{c}\text { Cohort Size } \\
\text { Full-time FTIC }\end{array}$ & \multicolumn{5}{|c|}{ N/A; No FTICs } \\
\hline
\end{tabular}

\section{6 - Year Rates}

From Same University

$\%$ Graduated

$\%$ Still Enrolled

$\%$ Success Rate

Notes: (1) Cohorts are based on undergraduate students who enter the institution in the Fall term (or Summer term and continue into the Fall term); (2) Success Rate measures the percentage of an initial

cohort of students who have either graduated or are still enrolled; (3) since degrees can be awarded after the last semester of coursework, the most recent year of data in this table provides preliminary

graduation rate data that may change with the addition of "late degrees". Late degrees reported in

conjunction with the IPEDS Graduation Rate Survey due in mid-April will be reflected in the following

year.

TABLE 4D. SUS Definition - Undergraduate Progression and Graduation Rates

for First-Time-in-College (FTIC) Students

\begin{tabular}{|c|c|c|c|c|c|}
\hline Term of Entry & Fall 2001 & Fall 2002 & Fall 2003 & Fall 2004 & $\begin{array}{l}\text { Fall } 2005 \\
\text { Preliminary }\end{array}$ \\
\hline $\begin{array}{c}\text { Cohort Size } \\
\text { Full- E Part-time }\end{array}$ & \multicolumn{5}{|c|}{ N/A; No FTICs } \\
\hline \multicolumn{6}{|l|}{4 - Year Rates } \\
\hline \multicolumn{6}{|l|}{ From Same University } \\
\hline $\begin{array}{l}\text { \% Graduated } \\
\% \text { Still Enrolled }\end{array}$ & \multicolumn{5}{|c|}{ N/A; No FTICs } \\
\hline \multicolumn{6}{|c|}{ From Other SUS University } \\
\hline $\begin{array}{l}\% \text { Graduated } \\
\% \text { Still Enrolled }\end{array}$ & \multicolumn{5}{|c|}{ N/A; No FTICs } \\
\hline \multicolumn{6}{|c|}{ From State University System } \\
\hline $\begin{array}{l}\text { \% Graduated } \\
\text { \% Still Enrolled } \\
\text { \% Success Rate }\end{array}$ & \multicolumn{5}{|c|}{ N/A; No FTICs } \\
\hline
\end{tabular}


TABLE 4D. SUS Definition - Undergraduate Progression and Graduation Rates

for First-Time-in-College (FTIC) Students

6 - Year Rates

From Same University

\begin{tabular}{l|l}
$\%$ Graduated & \\
\% Still Enrolled & N/A; No FTICs
\end{tabular}

N/A; No FTICs

$\%$ Graduated

$\%$ Still Enrolled

From State University System

\begin{tabular}{l|l}
$\%$ Graduated & \multirow{3}{*}{ N/A; No FTICs }
\end{tabular}

$\%$ Success Rate

Notes: (1) Cohorts are based on undergraduate students who enter the institution in the Fall term (or Summer term and continue into the Fall term); (2) Success Rate measures the percentage of an initial

cohort of students who have either graduated or are still enrolled; (3) since degrees can be awarded after the last semester of coursework, the most recent year of data in this table provides preliminary graduation rate data that may change with the addition of "late degrees". Late degrees reported in conjunction with the IPEDS Graduation Rate Survey due in mid-April will be reflected in the following year.
Section 4 - Undergraduate Education (continued)

TABLE 4E. SUS Definition - Undergraduate Progression and Graduation Rates

for AA Transfer Students

\begin{tabular}{|c|c|c|c|c|c|}
\hline Term of Entry & Fall 2003 & Fall 2004 & Fall 2005 & Fall 2006 & $\begin{array}{l}\text { Fall } 2007 \\
\text { Preliminary }\end{array}$ \\
\hline $\begin{array}{c}\text { Cohort Size } \\
\text { Full- E Part-time }\end{array}$ & \multicolumn{5}{|c|}{$\begin{array}{l}\text { Parsing of retention/graduation data at the campus-level cannot be } \\
\text { completed at this time. }\end{array}$} \\
\hline \multicolumn{6}{|l|}{2 - Year Rates } \\
\hline \multicolumn{6}{|l|}{ From Same University } \\
\hline$\%$ Graduated & \multirow{2}{*}{\multicolumn{5}{|c|}{$\begin{array}{l}\text { Parsing of retention/graduation data at the campus-level cannot be } \\
\text { completed at this time. }\end{array}$}} \\
\hline \% Still Enrolled & & & & & \\
\hline \multicolumn{6}{|c|}{ From Other SUS University } \\
\hline $\begin{array}{l}\text { \% Graduated } \\
\% \text { Still Enrolled }\end{array}$ & \multicolumn{5}{|c|}{$\begin{array}{l}\text { Parsing of retention/graduation data at the campus-level cannot be } \\
\text { completed at this time. }\end{array}$} \\
\hline \multicolumn{6}{|c|}{ From State University System } \\
\hline $\begin{array}{l}\% \text { Graduated } \\
\text { \% Still Enrolled } \\
\% \text { Success Rate } \\
\end{array}$ & \multicolumn{5}{|c|}{$\begin{array}{l}\text { Parsing of retention/graduation data at the campus-level cannot be } \\
\text { completed at this time. }\end{array}$} \\
\hline \multicolumn{6}{|l|}{4 - Year Rates } \\
\hline \multicolumn{6}{|l|}{ From Same University } \\
\hline $\begin{array}{l}\% \text { Graduated } \\
\text { \% Still Enrolled }\end{array}$ & \multicolumn{5}{|c|}{$\begin{array}{l}\text { Parsing of retention/graduation data at the campus-level cannot be } \\
\text { completed at this time. }\end{array}$} \\
\hline \multicolumn{6}{|c|}{ From Other SUS University } \\
\hline $\begin{array}{l}\text { \% Graduated } \\
\% \text { Still Enrolled }\end{array}$ & \multicolumn{5}{|c|}{$\begin{array}{l}\text { Parsing of retention/graduation data at the campus-level cannot be } \\
\text { completed at this time. }\end{array}$} \\
\hline \multicolumn{6}{|c|}{ From State University System } \\
\hline $\begin{array}{l}\% \text { Graduated } \\
\% \text { Still Enrolled } \\
\% \text { Success Rate } \\
\end{array}$ & \multicolumn{5}{|c|}{$\begin{array}{l}\text { Parsing of retention/graduation data at the campus-level cannot be } \\
\text { completed at this time. }\end{array}$} \\
\hline \multicolumn{6}{|c|}{$\begin{array}{l}\text { Notes: (1) Cohorts are based on undergraduate students who enter the institution in the Fall term (or } \\
\text { Summer term and continue into the Fall term); (2) Success Rate measures the percentage of an initial } \\
\text { cohort of students who have either graduated or are still enrolled; (3) since degrees can be awarded after } \\
\text { the last semester of coursework, the most recent year of data in this table provides preliminary } \\
\text { graduation rate data that may change with the addition of "late degrees". Late degrees reported in } \\
\text { conjunction with the IPEDS Graduation Rate Survey due in mid-April will be reflected in the following } \\
\text { year. }\end{array}$} \\
\hline
\end{tabular}




\section{Section 4 - Undergraduate Education (continued)}

TABLE 4F. SUS Definition - Undergraduate Progression and Graduation Rates

for Other Transfer Students

\begin{tabular}{|c|c|c|c|c|c|}
\hline Term of Entry & Fall 2002 & Fall 2003 & Fall 2004 & Fall 2005 & $\begin{array}{l}\text { Fall } 2006 \\
\text { Preliminary }\end{array}$ \\
\hline $\begin{array}{l}\text { Cohort Size } \\
\text { Full- E Part-time }\end{array}$ & \multicolumn{5}{|c|}{$\begin{array}{l}\text { Parsing of retention/graduation data at the campus-level cannot be } \\
\text { completed at this time. }\end{array}$} \\
\hline \multicolumn{6}{|l|}{5 - Year Rates } \\
\hline \multicolumn{6}{|l|}{ From Same University } \\
\hline $\begin{array}{l}\% \text { Graduated } \\
\% \text { Still Enrolled }\end{array}$ & \multicolumn{5}{|c|}{$\begin{array}{l}\text { Parsing of retention/graduation data at the campus-level cannot be } \\
\text { completed at this time. }\end{array}$} \\
\hline \multicolumn{6}{|c|}{ From Other SUS University } \\
\hline $\begin{array}{l}\% \text { Graduated } \\
\% \text { Still Enrolled }\end{array}$ & \multicolumn{5}{|c|}{$\begin{array}{l}\text { Parsing of retention/graduation data at the campus-level cannot be } \\
\text { completed at this time. }\end{array}$} \\
\hline \multicolumn{6}{|c|}{ From State University System } \\
\hline $\begin{array}{l}\text { \% Graduated } \\
\text { \% Still Enrolled } \\
\% \text { Success Rate }\end{array}$ & \multicolumn{5}{|c|}{$\begin{array}{l}\text { Parsing of retention/graduation data at the campus-level cannot be } \\
\text { completed at this time. }\end{array}$} \\
\hline \multicolumn{6}{|c|}{$\begin{array}{l}\text { Notes: (1) Cohorts are based on undergraduate students who enter the institution in the Fall term (or } \\
\text { Summer term and continue into the Fall term); (2) Success Rate measures the percentage of an initial } \\
\text { cohort of students who have either graduated or are still enrolled; (3) since degrees can be awarded after } \\
\text { the last semester of coursework, the most recent year of data in this table provides preliminary } \\
\text { graduation rate data that may change with the addition of "late degrees". Late degrees reported in } \\
\text { conjunction with the IPEDS Graduation Rate Survey due in mid-April will be reflected in the following } \\
\text { year. }\end{array}$} \\
\hline
\end{tabular}

\section{TABLE 4G. Baccalaureate Degrees Awarded}

\begin{tabular}{|c|c|c|c|c|c|}
\hline TABLE 4G. Baccalaureate Degrees Awarded \\
\hline & $\mathbf{2 0 0 6 - 0 7}$ & $\mathbf{2 0 0 7 - 0 8}$ & $\mathbf{2 0 0 8 - 0 9}$ & $\mathbf{2 0 0 9 - 1 0}$ & $\mathbf{2 0 1 0 - 1 1}$ \\
\hline TOTAL & 222 & 233 & 300 & 254 & 284 \\
\hline
\end{tabular}

\section{TABLE 4H. Baccalaureate Degrees Awarded in Areas of Strategic Emphasis}

\begin{tabular}{|c|c|c|c|c|c|}
\hline & $\mathbf{2 0 0 6 - 0 7}$ & $\mathbf{2 0 0 7 - 0 8}$ & $\mathbf{2 0 0 8 - 0 9}$ & $\mathbf{2 0 0 9 - 1 0}$ & $\mathbf{2 0 1 0 - 1 1}$ \\
\hline Education & 0 & 0 & 0 & 0 & 0 \\
\hline Health Professions & 2 & 1 & 5 & 1 & 0 \\
\hline $\begin{array}{c}\text { Science, Technology, } \\
\text { Engineering, and Math }\end{array}$ & 16 & 20 & 18 & 22 & 18 \\
\hline $\begin{array}{c}\text { Security and Emergency } \\
\text { Services }\end{array}$ & 9 & 14 & 21 & 20 & 17 \\
\hline Globalization & 1 & 0 & 1 & 1 & 0 \\
\hline SUBTOTAL & $\mathbf{2 8}$ & $\mathbf{3 5}$ & $\mathbf{4 5}$ & $\mathbf{4 4}$ & $\mathbf{3 5}$ \\
\hline
\end{tabular}

USF Polytechnic 2011 Annual Report

\section{Section 4 - Undergraduate Education (continued)}

TABLE 4I. Baccalaureate Degrees Awarded to Underrepresented Groups

\begin{tabular}{l|l|l|l|}
\hline $2006-07$ & $2007-08$ & $2008-09$ \\
\hline
\end{tabular}

2009-10

Non-Hispanic Black Number of Baccalaureate Degrees

Percentage of All

Baccalaureate Degrees

\begin{tabular}{c|c|c|c|c}
23 & 27 & $\begin{array}{c}35 \\
\text { Increase }^{*}\end{array}$ & 26 & 30 \\
\hline $11 \%$ & $12 \%$ & $\begin{array}{c}12 \% \\
\text { Maintain }^{*}\end{array}$ & $10 \%$ & $11 \%$ \\
\hline
\end{tabular}

Hispanic

\begin{tabular}{|c|c|c|c|c|c|}
\hline $\begin{array}{c}\text { Number of } \\
\text { Baccalaureate Degrees }\end{array}$ & 20 & 24 & $\begin{array}{c}28 \\
\text { Increase* }\end{array}$ & 29 & 20 \\
\hline $\begin{array}{c}\text { Percentage of All } \\
\text { Baccalaureate Degrees }\end{array}$ & $9 \%$ & $10 \%$ & $\begin{array}{c}10 \% \\
\text { Increase* }\end{array}$ & $12 \%$ & $7 \%$ \\
\hline Pell-Grant Recipients & 89 & 92 & $\begin{array}{c}104 \\
\text { Increase* }\end{array}$ & 97 & 121 \\
\hline $\begin{array}{c}\text { Number of } \\
\text { Baccalaureate Degrees }\end{array}$ & $41 \%$ & $41 \%$ & $\begin{array}{c}35 \% \\
\text { Maintain* }\end{array}$ & $38 \%$ & $43 \%$ \\
\hline $\begin{array}{c}\text { Percentage of All } \\
\text { Baccalaureate Degrees }\end{array}$ &
\end{tabular}

Note: Pell-Grant recipients are defined as those students who have received a Pell grant from any SUS Institution within six years of graduation. This does not include degrees awarded to students whose

race/ethnicity code is missing (or not reported) or for students who are non-resident aliens.

Note*: Directional goals for the 2012-13 year were established in the 2010 University Work Plan.

TABLE 4J. Baccalaureate Completion Without Excess Credit Hours

\begin{tabular}{c|c|c|c|c|c|}
\hline $\begin{array}{c}\% \text { of Total Baccalaureate } \\
\text { Degrees Awarded } \\
\begin{array}{c}\text { Within } 110 \% \text { of Hours } \\
\text { Required for Degree }\end{array}\end{array}$ & $\mathbf{2 0 0 6 - 0 7}$ & $\mathbf{2 0 0 7 - 0 8}$ & $\mathbf{2 0 0 8 - 0 9}$ & $\mathbf{2 0 0 9 - 1 0}$ & $\mathbf{2 0 1 0 - 1 1}$ \\
\hline
\end{tabular}

\section{TABLE 4K. Undergraduate Course Offerings}

\begin{tabular}{|c|c|c|c|c|c|}
\hline & Fall 2006 & Fall 2007 & Fall 2008 & Fall 2009 & Fall 2010 \\
\hline $\begin{array}{c}\text { Number of } \\
\text { Course Sections }\end{array}$ & 106 & 107 & 85 & 91 & 106 \\
\hline \multicolumn{6}{|c|}{ Percentage of Undergraduate Course Sections by Class Size } \\
\hline Fewer than 30 Students & $88 \%$ & $74 \%$ & $65 \%$ & $79 \%$ & $89 \%$ \\
\hline 30 to 49 Students & $12 \%$ & $26 \%$ & $34 \%$ & $21 \%$ & $11 \%$ \\
\hline 50 to 99 Students & $0 \%$ & $0 \%$ & $1 \%$ & $0 \%$ & $0 \%$ \\
\hline 100 or More Students & $0 \%$ & $0 \%$ & $0 \%$ & $0 \%$ & $0 \%$ \\
\hline
\end{tabular}




\section{Section 4 - Undergraduate Education (continued)}

TABLE 4L. Faculty Teaching Undergraduates

\begin{tabular}{|l|l|l|l|r|}
\hline $2006-07$ & $2007-08$ & $2008-09$ & $2009-10$ & $2010-11$ \\
\hline
\end{tabular}

Percentage of Credit Hours Taught by:

\begin{tabular}{|l|c|c|c|c|c|}
\hline Faculty & $57 \%$ & $43 \%$ & $40 \%$ & $46 \%$ & $60 \%$ \\
\hline Adjunct Faculty & $38 \%$ & $55 \%$ & $59 \%$ & $53 \%$ & $39 \%$ \\
\hline Graduate Students & $4 \%$ & $0 \%$ & $0 \%$ & $0 \%$ & $0 \%$ \\
\hline Other Instructors & $1 \%$ & $2 \%$ & $1 \%$ & $1 \%$ & $1 \%$ \\
\hline
\end{tabular}

Note: The definition of faculty varies for Tables $4 \mathrm{~L}, 4 \mathrm{M}$ and $4 \mathrm{~N}$. For Faculty Teaching Undergraduates,

the definition of faculty is based on pay plans 01,02 , and 22 .

\section{TABLE 4M. Undergraduate Instructional Faculty Compensation}

\begin{tabular}{|c|c|c|c|c|c|}
\hline & 2006-07 & 2007-08 & 2008-09 & 2009-10 & 2010-11 \\
\hline $\begin{array}{c}\text { Average Salary and } \\
\text { Benefits for Faculty } \\
\text { Who Teach at Least One } \\
\text { Undergraduate Course }\end{array}$ & $\$ 89,184$ & $\$ 92,441$ & $\$ 93,108$ & $\$ 96,578$ & $\$ 96,228$ \\
\hline
\end{tabular}

\section{TABLE 4N. Student/Faculty Ratio}

\begin{tabular}{|c|c|c|c|c|c|}
\hline & Fall 2006 & Fall 2007 & Fall 2008 & Fall 2009 & Fall 2010 \\
\hline Student-to-Faculty Ratio & 17 & 17 & 22 & 23 & 15 \\
\hline
\end{tabular}

Note: The definition of faculty varies for Tables $4 \mathrm{~L}, 4 \mathrm{M}$ and $4 \mathrm{~N}$. For Student/Faculty Ratio, the definition of faculty is consistent with Common Data Set reporting (which counts full-time equivalent instructional faculty as full-time faculty plus $1 / 3$ part-time faculty).

\section{TABLE 4O. Professional Licensure/Certification Exams for Undergraduate Programs} \begin{tabular}{|l|l|l|l|l|}
$\mathbf{2 0 0 6 - 0 7}$ & $2007-08$ & $2008-09$ & $2009-10$ & $\mathbf{2 0 1 0 - 1 1}$ \\
\hline
\end{tabular}

Nursing: National Council Licensure Examination for Registered Nurses

\begin{tabular}{l|l} 
Examinees & \\
$y n$ &
\end{tabular} Not Applicable

\section{Section 4 - Undergraduate Education (continued)}

TABLE 4P. Tuition Differential Fee

\begin{tabular}{|c|c|c|c|}
\hline TABLE 4P. Tuition Differential Fee & 2009-10 & 2010-11 & $\begin{array}{c}\text { 2011-12 } \\
\text { Projected }\end{array}$ \\
\hline $\begin{array}{c}\text { Total Revenues Generated } \\
\text { By the Tuition Differential }\end{array}$ & $\$ 144,450$ & $\$ 354,468$ & $\$ 569,837$ \\
\hline $\begin{array}{c}\text { Unduplicated Count of Students } \\
\text { Receiving a Financial Aid Award } \\
\text { Funded by Tuition Differential Revenues }\end{array}$ & 60 & 129 & \\
\hline $\begin{array}{c}\text { Average Amount of Awards } \\
\text { Funded by Tuition Differential Revenues } \\
\text { (per student receiving an award) }\end{array}$ & $\$ 894$ & $\$ 823$ & \\
\hline $\begin{array}{c}\text { Number of Students Eligible for a } \\
\text { Florida Student Assistance Grant (FSAG) }\end{array}$ & 173 & 0 & \\
\hline $\begin{array}{c}\text { Number of FSAG-Eligible Students } \\
\text { Receiving a Waiver } \\
\text { of the Tuition Differential }\end{array}$ & 0 & $\$ 0$ & \\
\hline $\begin{array}{c}\text { Value of Tuition Differential Waivers } \\
\text { Provided to FSAG-Eligible Students }\end{array}$ & $\$ 0$ & & \\
\hline
\end{tabular}




\section{Section 5 - Graduate Education}

\begin{tabular}{|c|c|c|c|c|c|c|}
\hline TABLE 5A. Graduate Degree Program Changes in AY 2010-11 \\
\hline Title of Program & $\begin{array}{c}\text { Six-digit } \\
\text { CIP } \\
\text { Code }\end{array}$ & $\begin{array}{c}\text { Degree } \\
\text { Level }\end{array}$ & $\begin{array}{c}\text { Date of } \\
\text { UBOT } \\
\text { Action }\end{array}$ & $\begin{array}{c}\text { Starting } \\
\text { or Ending } \\
\text { Term }\end{array}$ & $\begin{array}{c}\text { Date of } \\
\text { Board of } \\
\text { Governors } \\
\text { Action }\end{array}$ & Comments \\
\hline
\end{tabular}

New Programs

$\mathrm{N} / \mathrm{A}$

\section{Terminated Programs}

N/A

Inactive Programs

N/A

\section{New Programs Considered By University But Not Approved}

$\mathrm{N} / \mathrm{A}$

Note: This table does not include new majors or concentrations added under an existing degree program CIP Code. This table reports the program changes between May 5, 2010 and May 4, 2011. New Programs are proposed new degree programs that have been completely through the approval process at the university and, if appropriate, the Board of Governors. Terminated Programs are degree programs for which the entire CIP Code has been terminated and removed from the university's inventory of degree programs. Inactive Programs are degree programs for which enrollments have been temporarily suspended for the entire CIP Code, but the program CIP Code has not been terminated.

\section{TABLE 5B. Graduate Degrees Awarded}

\begin{tabular}{|l|c|c|c|c|c|}
\hline \multicolumn{1}{|c|}{ TOTAL } & $\mathbf{2 0 0 6 - 0 7}$ & $\mathbf{2 0 0 7 - 0 8}$ & $\mathbf{2 0 0 8 - 0 9}$ & $\mathbf{2 0 0 9 - 1 0}$ & $\mathbf{2 0 1 0 - 1 1}$ \\
\hline Masters and Specialist & $\mathbf{8 0}$ & $\mathbf{6 6}$ & $\mathbf{1 0 3}$ & $\mathbf{7 8}$ & $\mathbf{6 4}$ \\
\hline Research Doctoral & 80 & 66 & 103 & 78 & 64 \\
\hline Professional Doctoral & 0 & 0 & 0 & 0 & 0 \\
\hline a) Medicine & 0 & 0 & 0 & 0 & 0 \\
\hline b) Law & 0 & 0 & 0 & 0 & 0 \\
\hline c) Pharmacy & 0 & 0 & 0 & 0 & 0 \\
\hline
\end{tabular}

Note: The total number of Professional Doctoral degrees includes other programs that are not specifically identified in lines $a, b$, and $c$.

\section{Section 5 - Graduate Education (continued)}

TABLE 5C. Graduate Degrees Awarded in Areas of Strategic Emphasis

\begin{tabular}{|c|c|c|c|c|c|}
\hline & $\mathbf{2 0 0 6 - 0 7}$ & $\mathbf{2 0 0 7 - 0 8}$ & $\mathbf{2 0 0 8 - 0 9}$ & $\mathbf{2 0 0 9 - 1 0}$ & $\mathbf{2 0 1 0 - 1 1}$ \\
\hline Education & 19 & 22 & 29 & 11 & 10 \\
\hline $\begin{array}{c}\text { Health Professions } \\
\text { Science, Technology, } \\
\text { Engineering, and Math }\end{array}$ & 0 & 0 & 2 & 0 & 0 \\
\hline $\begin{array}{c}\text { Security and Emergency } \\
\text { Services }\end{array}$ & 0 & 0 & 0 & 0 & 0 \\
\hline Globalization & 0 & 0 & 0 & 1 & 0 \\
\hline SUBTOTAL & $\mathbf{2 0}$ & $\mathbf{2 3}$ & $\mathbf{3 1}$ & $\mathbf{1 2}$ & $\mathbf{1 0}$ \\
\hline
\end{tabular}

Section 6 - Research and Economic Development

\section{TABLE 6A. Research and Development}

R\&D Expenditures

Federally Funded

Expenditures

(Thousand \$)

Total Expenditures

(Thousand \$)

\begin{tabular}{l|l|l|}
\hline $2005-06$ & $2006-07$ & $2007-08$ \\
\hline
\end{tabular}

2008-09

2009-10

Total R\&D

Tenure-Earning Faculty

Member (\$)

Technology Transfer

Invention Disclosures

Total U.S. Patents Issued

Patents Issued Per 1,000

Full-Time, Tenure and

Tenure-Earning Faculty

Total Number of Licenses/

Options Executed

Reported at the USF System level

Reported at the USF System level in previous years

Total Licensing Income

Received (\$)

Total Number of Start-Up

Companies

Note: Awards and Expenditures are based on the National Science Foundation's annual Survey of R\&D

Expenditures at Universities and Colleges (data include Science \& Engineering and non-Science \&

Engineering awards). Technology Transfer data are based on the Association of University Technology

Managers Annual Licensing Survey. 